\title{
EXPLORING THE DYNAMIC THAT INFLUENCE STUDENTS’ INSIGHT IN THE EFL SPEAKING CLASSROOM
}

\author{
Dr. Deepika Nelson ${ }^{1 *}$ \\ *1Associate Professor E-mail ID-dr.deepikanelson@gmail.com
}

*Corresponding Author: -

E-mail ID-dr.deepikanelson@gmail.com

\begin{abstract}
: -
Learners all over the world find complexity in learning English. Several, rationales that hinder their learning process. Motivation is one of the insights that influence the students in the speaking classroom. Dornyei, (2005) stated " without sufficient motivation, even individuals with the most remarkable abilities cannot accomplish long term goals, and neither appropriate curricula and good teaching is enough to ensure students achievement. In order to obtain a deeper insight into students reflection on their motivational process, Madrid and Canado(2001) defined a concept of motivation as one's internal state which is influenced by certain need or beliefs which engender constructive attitudes and interest towards a goal. These attitudes later create constant endeavor on entity because of the satisfaction experienced along with the positive results that have been obtained. This study is going to explored the dynamics that influence students' insight in the EFL speaking classroom. A Mixed method approach which included both qualitative and quantitative method was used. A systematic random sampling technique was employed.
\end{abstract}

Keywords: - Motivation, Insight, Dynamics. Speaking skill. 


\section{INTRODUCTION:}

English is being given a lot of importance all over the world. The Ethiopian government (2010), designed a new language teaching strategy by organizing classroom students in the form of one-to-five to promote high quality learning and to make students active participants in their learning activities and more likely to perform well academically. the government language strategy intends to improve learners' language competence because for many years Ethiopian students have lack of motivation towards English lesson especially, in speaking. Speaking seems to be the most important skills of all the four skills (listening, speaking, reading and writing) because people who know a language are usually referred to as speakers of that language (Ur, 1996). In Ethiopian speaking skill has no part in national examination .It is perceived by most teachers as the neglected part of the materials. Students speaking has nothing to do with pass or fail. Thus it may be causing the students' lack of motivation to learn the speaking skill. They may fail to see the relevance of learning the speaking skill to their real -life communication. Their interest will probably be to pass the examination without realizing the importance of speaking and listening in real world or career and higher education (Jin and Wang, 1993).Hence by Motivation for learning a second language is defined as the learner's orientation with regard to the goal of learning a second language. (Rookes and Schmidt, 1991).

Motivation is a complex construct, and there are many factors that might inspire students to master a foreign language. However, motivation has been a major problem for most learners of English as a foreign language not only in high schools but also in colleges and universities in Ethiopia especially in learning speaking skill. Both Dornyei (2001) and Little John (2001) point out that self esteem and confidence are crucial factors influencing motivational that the selfesteem of learners is influenced by feedback from teachers. Therefore "Motivation is a theoretical construct used to explain the initiation, direction, intensity, and persistence of behaviour, especially goal-directed behavior. Ryan and Deci (2000, 68) specify these needs as autonomy, competence and relatedness and add that "competence, autonomy and relatedness, when satisfied, yield enhanced self-motivation and mental health and, when thwarted, lead to diminished motivation and wellbeing". Mastering the art of teaching and learning is always dependent on the progress of students and the way students are influenced by the effectiveness of every positive attitude regarding their education. There are a lot of factors, such as, classroom's structure, lessons, various kinds of assessments, strategies, etc that play a very important role in deciding the progress and effectiveness of teacher-student learning and teaching. However, attaining mastery in the profession of teaching requires more than the traditional practices of a classroom. This allows every teacher to enhance the motivation skills in their students from the basic level (Jackson, 2011). Some local researchers like Moges,(2006), Eshete (2004), accentuated on researching, problems students encounter in speaking in the EFL classroom, the practice of teaching speaking skill, and other more or less similar issues. Their findings were motivation and students' achievement has causal relationships. However, the researcher focused on the factors that influence students speaking motivation apart from this absence of authentic speaking materials and large class size were the main problem of the students to learn speaking lesson in the EFL classroom.

The current study focuses on two Issues:

1. What are the dynamics that influence students' motivation in EFL speaking classroom?

2. What are the approaches used by the teachers to overcome students' speaking motivational problems in EFL speaking classroom?

\section{Methodology:}

A valid method for researching the students' level of motivation and the dynamics that influence motivation in EFL speaking class, was the Mixed method approach, both qualitative and quantitative was used.

The participants of the study were 35 English undergraduate students of Haramaya University who were selected through systematic random sampling technique, whereas all the available sample of 5 teachers teaching them were considered because of their involvement in teaching English language and their understanding about students' attitude towards speaking skill and what motivates the students to speak or not to speak effectively.

Classroom Observation was used as a major tool in the study. A checklist was designed to identify the dynamics that influenced student's motivation in EFL speaking class. The major criteria of the checklist included what is the role of the teacher in teaching speaking skill, what the learners are supposed to do during speaking lesson, do the learner contribute enthusiastically in the speaking lesson, how do the activities the learners are involved and what difficulties are observed in the classroom when speaking is practiced. To assess the level of student's motivation for practicing English speaking activity, Questionnaire was another tool. Both close ended and open ended items were included in the questionnaires. The other data collecting instrument that was employed was the semi-structured interview of the teachers, to find out dynamics that influence motivation in EFL speaking class and competency. 


\section{Results and Discussion:}

3.1 The dynamics that influence students' motivation in EFL speaking classroom

3.1.1 The Students' Poor Prior Knowledge of the English Language

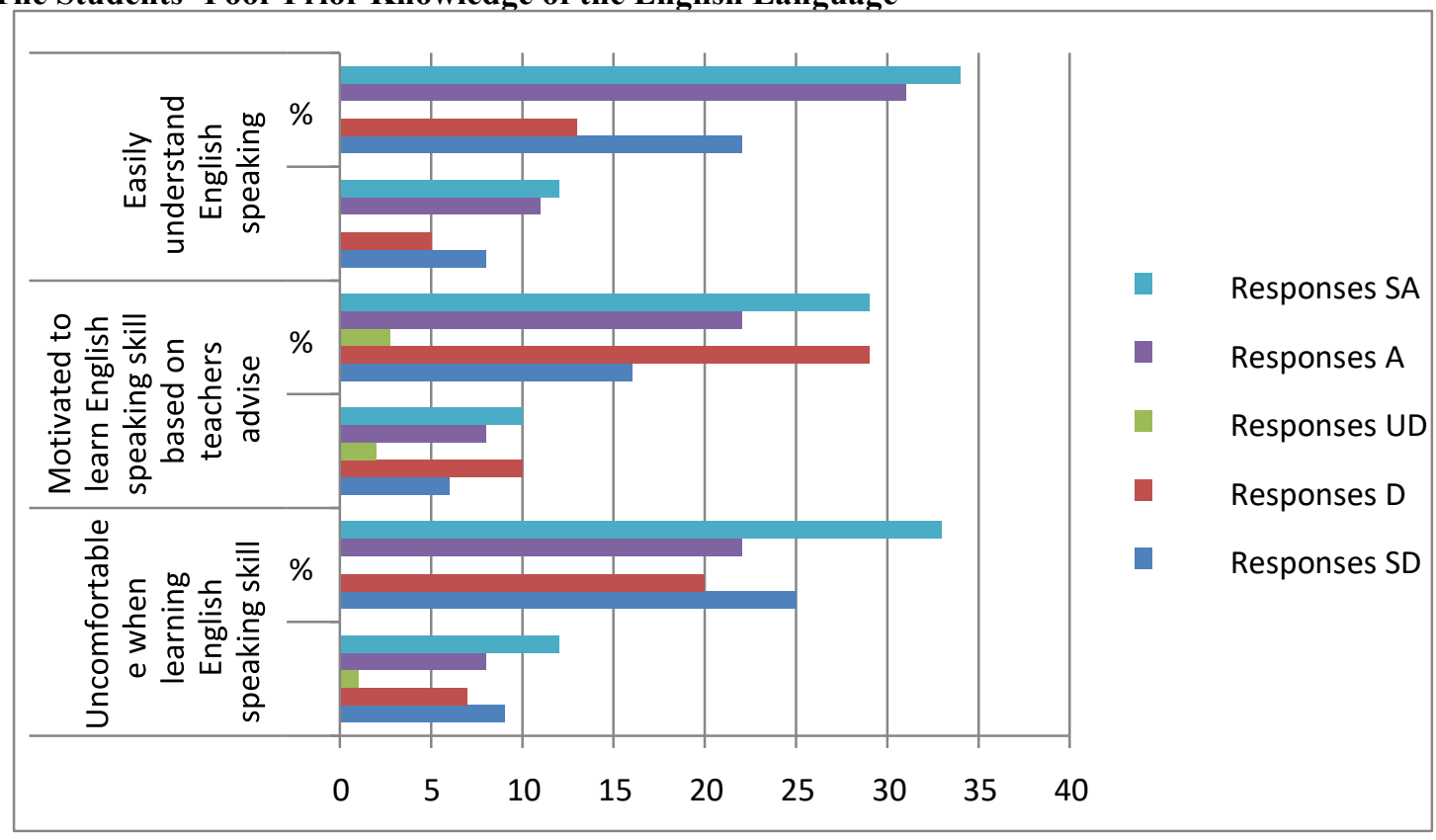

Chart No1: Prior knowledge of students in English speaking skill

Chart No1 we see that $12(33 \%)$ and 8(22\%) strongly agree and Agree, to the statement that they are not in their comfort zone when they learn English speaking skills, because they do not understand the significance of speaking skill in the classroom. Whereas during classroom observation students were overall not participating and ignorant while the Faculty asked them to practice oral activities except for $r$ few outstanding students who took an initiative .Further from the results of the teachers' interview 'What are the difficulty that de motivate students' performance in speaking class? Out of the Five teachers interviewed, three teachers responded that students ' poor prior knowledge of English language made them less confident to participate and they were a misfit with the complexity of the speaking skill.

The following Item "Are they motivated to learn English speaking skill based on their teacher's advice and strategies of teaching and learning speaking. The results show that, $8(22 \%)$ of the students replied agree, 10(29\%), strongly agree whereas $45 \%$ said strongly disagree and disagree and 2 students gave no reply. This shows that it is the necessity of the students to get useful advice from their teachers to get support in the speaking skill. However, when we see the response of teachers' interview for, Was It discouraging for the students to get constructive advice and encouragement from their teachers? For instance a teacher comprehended that, T1

"We are really face difficulty in encouraging our students to actively participate in learning speaking; most of them came with poor background of English. In general it is difficult to help them speak effectively." On the other hand, the teachers said that there are very few teaching speaking materials such as recordings and their students' lack of motivation instead of encouraging the students to speak. Therefore, it can be infered that because enough of attention was not paid to speaking in the past, the teachers and students are not interested in teaching and learning the speaking skill as an important aspect of the skills due to the poor background of the students. In addition to this, the result of the classroom observation indicated that teachers' strategies of teaching speaking is not encouraging enough and motivating in the classroom. For instance, they did not use variety of teaching strategies in teaching speaking. As Richards (1992) noted, background knowledge plays an important role in the improvement of speaking skill.

Once the lesson content and teaching techniques retrieve speakers' background knowledge and apply them to their interest, learners are motivated to learn the language.

The last Item focused on the prior knowledge of the English. 65\% reported that they agree to the statement, 'Easily understand English by speaking, have a great motivation for learning speaking,' This indicated that the students' background for speaking foreign language is a major hurdle to motivate speaking skill. Furthermore, the result of the teachers' response for the interview item number 5 revealed, the teachers themselves seemed not to enjoy or like teaching the speaking skill in contrast to the teaching of other skills. The cause for this was that they usually feel perturbed because the students do not give response and majorly do not actively involved in speaking activities. Most of the teachers did not even follow the three stages of teaching speaking skill. The students also responded for the open-ended question item 15indicating that they could not find anything to motivate them in learning the speaking skill in the classroom. Generally, it is possible to conclude that the students' poor background knowledge of the English language influenced their attitude or interest negatively, and this had an impact on the teachers' attitude and interest to teach the skill in a very motivating way.

To conclude, according to the above findings, the learners' prior knowledge of the English language in general was the major factor to deter the students' speaking motivation in the classroom. In relation to this, the lack of motivation may be caused by different variables such as poor prior knowledge and in ability to understand the speaking text, and other 
students' own or perceptions may hinder the motivation of the students towards learning the speaking skill. In relation to this, "For people speaking and listening to a foreign language an unknown word can be like a suddenly dropped barrier causing them to stop and think about the meaning of the word and thus making them miss the next part of the speech (Anderson, 1988: 35).

\subsubsection{Attitude of the Students towards the Speaking Skill}

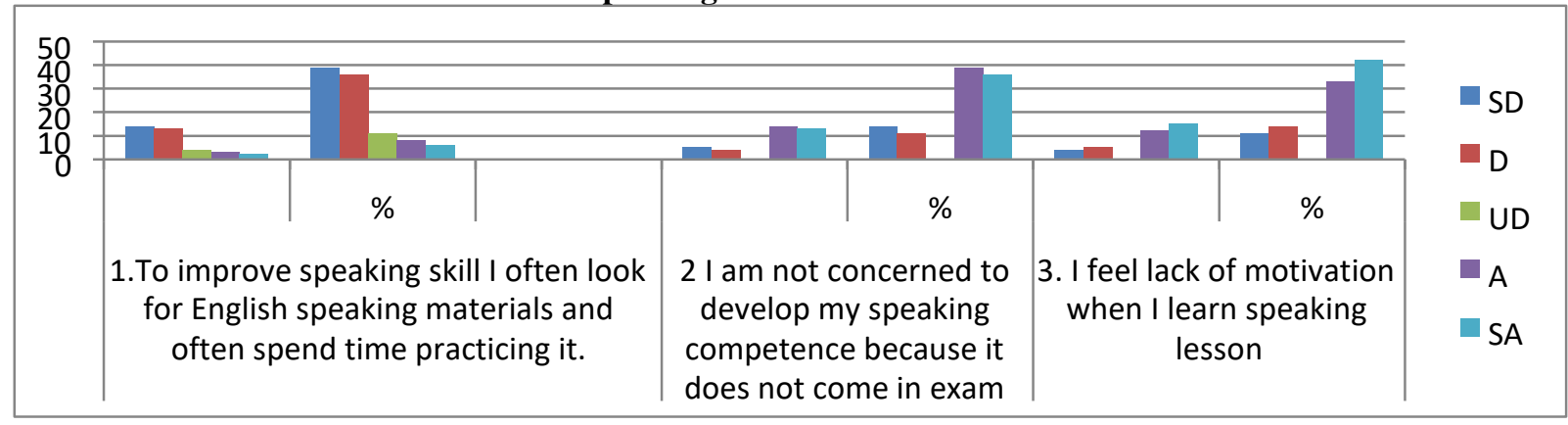

Chart No 2 Attitude of students towards speaking skill

In the above chart the Item 1 shows that, a significant number of students, $38.8 \%$ students reported strongly disagree, and said that they did not look for or study English speaking materials, and they did not spend their time practicing the skill as they did for other skills such as grammar and reading, whereas other 36 responded disagree, $16.2 \%$ strongly agree and agree respectively and the rest $11 \%$ responded undecided. Item $2,74.8 \%$ strongly agreed and agree to the statement that they are not concerned to develop their speaking competence because it does not come in exam. The teachers interview also overall said that they too do not focus much on speaking skill activities given in the book, as they are not an integral part of exam. Similarly the classroom observation too showed the lack of motivation of teachers to teach this skill and most of them escape to focus more on other skills from examination point of view. Thus, this proposes that the students are not motivated towards the speaking skill as they consider the skill a difficult skill. In addition to this most students have said that speaking materials in the textbook were not interesting to motivate them. So they usually paid no attention to the speaking skill. In relation, the majority of the interviewed teachers ( 4 of them) reported their answers as 'no' to the question, To appraise the students' feelings in learning the speaking skill in the classroom showing that the students often did not pay attention in practicing the speaking skill in the classroom,. This in turn indicates that the students' extrinsic motivation, that is, looking for speaking materials which were relevant to the development of speaking skill seemed difficult to find. The students looked very nervous when they spoke in front of the class. Sometimes, they did not know what to say and kept silent and hence developed lack of motivation and interest in the EFL speaking classroom. In brief, the findings from the questionnaires delivered to both the teachers and the students showed that when the students learn speaking, they encountered many problems. Al-Housni (2014) states, "Many studies have indicated that oral language development has largely been neglected in the classroom, and most of the time, oral language in the classroom is used more by teachers than by students. However, oral language, even as used by the teacher, hardly ever functions as a means for students to gain knowledge and explore ideas." That is, the teacher should recently be a facilitator and the one who guides the lesson and not the one who gives that lesson. Apparently, oral expression has not much significance in learning. Hence, learners would find difficulty in speaking English even if they were university students.

\subsection{The approaches used by the teachers to overcome students' speaking motivational problems in EFL speaking classroom}

A number of teachers believe that teaching speaking skill in EFL classroom is important as a part of language learning, they do not give the sufficient time to do that, and say the time is not available. If a chance or a time is obtainable to allow students to speak, teachers prefer just moving on to accomplish other tasks like reading and writing (Bani-abdelrahman, 2013, p.81). Language is a way that the teacher uses to present deferent activities during lessons. In a balanced activities approach, the teacher uses a variety of activities from different categories ofinput and output. Learners with different levels benefit from that variety since it is more motivating to result effective language learning. The capacity to speak a language is the product of language learning as many learners often thought, but speaking is also a critical part of the language learning process. Effective instructors teach students speaking strategies; using minimal responses, recognizing script, and using language to talk about language, and then the students would develop their knowledge of the language and their confidence to use it. 


\subsubsection{The Role of the teachers in the EFL classroom}

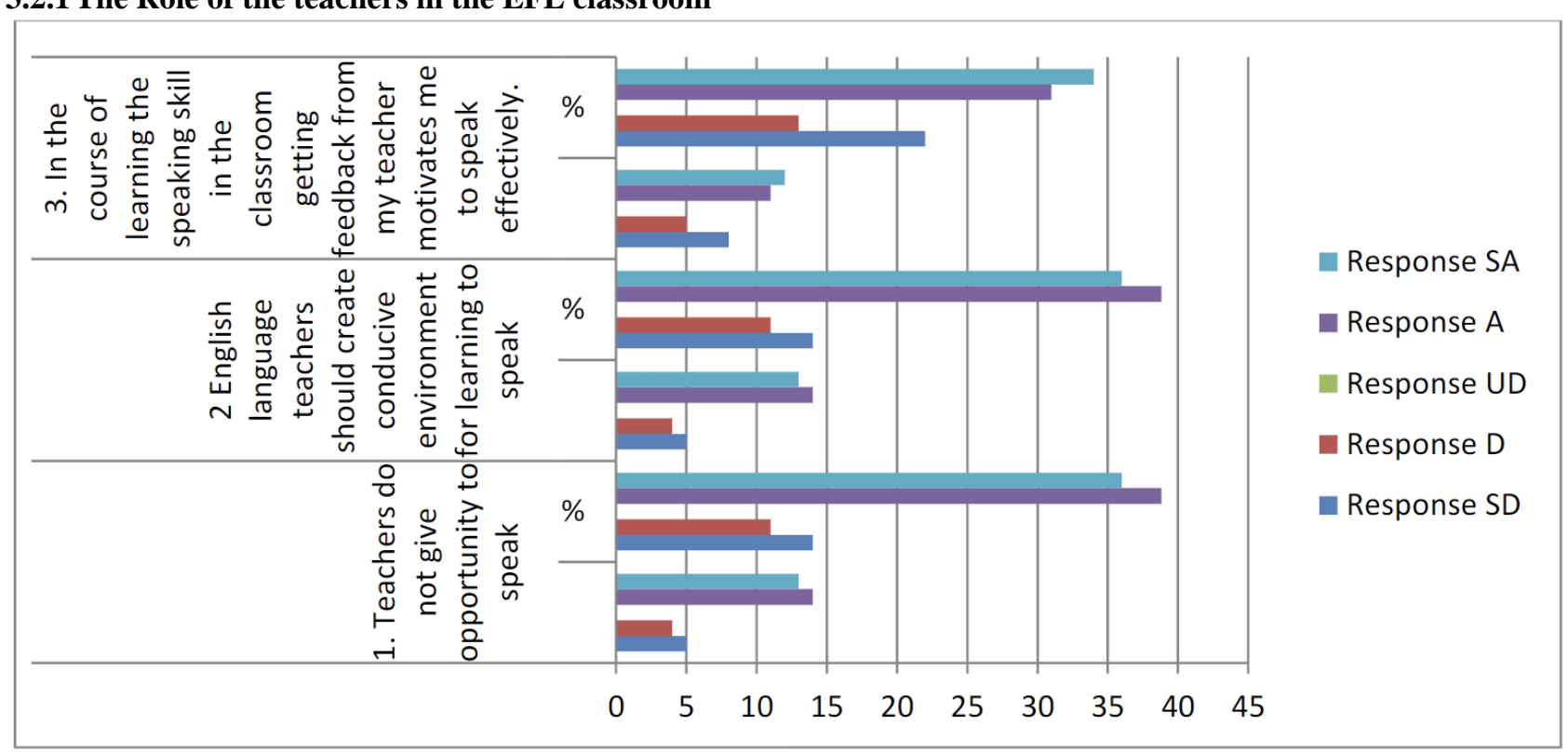

Chart No 3: Role of teachers

Teachers today confront the challenge of educating a continually expanding number of linguistically diverse students. Students were asked if their teacher gave them opportunity to speak in English during speaking lesson classes. The results in above chart No3 shows that, that $13(36 \%)$ of them responded strongly agree that their teachers do not give them opportunity to speak in English so as to enhance their speaking capacity and motivation. 14 (38.8\%) of them responded agree. 9 students $14 \%$ reported strongly disagree and disagree respectively. This consequence shows that English language teachers do not persuade their students to take part in the speaking activity during English speaking class. This usually causes students to be passive participants during the speaking lesson class. during classroom observation it was noticed that the teacher focused mainly to cover the lesson in the given time hardly focusing on these speaking activities. During teachers interview also one of the teachers said we have limited time to complete the syllabus usually we focus on exam related skills.

When we see item 2. There we find that the nonexistence of conducive environment. $36 \%$ of students strongly agreed that their teacher should create conducive environment in speaking classes to help them be motivated. $38 \%$ gave affirmative agreement. The rest $26 \%$ have reported strongly disagree and disagree respectively. During the classroom observation the teachers spent most of their teaching time by explaining grammar and vocabulary. Here, learners were not given opportunity neither encouraged to participate in those activities which were not related from examination point of view. According to Item $3,12(34 \%)$ of the students have strongly agreed that in their course of learning the speaking skills, getting feedback from their teachers motivates them; while significant number of students 11(31\%) have responded agree. On the other hand, $5(13 \%)$ and $8(22 \%)$ have reported that they disagree and strongly disagree of getting feedback from their teachers which encourage them to speak effectively. From this we can infer that the students need to get feedback from their teachers for motivation or encouragement towards effective speaking. According to the classroom observation results, the teachers lacked the tendency of giving feedback and majority of the teachers were not seen giving feedback to the students immediately, or after the end of each speaking lesson.

From the above analysis of the data, the teachers role significantly affects students learning speaking in the classroom. The teachers' role may be apparent failure to give chance to students to speak in the classroom, inability to create conducive environment for learners, inability to give feedback. Li (2005) comments, to implement effective teaching strategies, engage students in setting learning goals; make sure that goals are challenging, but achievable. Recognize individual difference, encourage students to take ownership for their learning and to reflect on what they have learned and accomplished, give students individual feedback, remind them that successes often requires persistence and a willingness to overcome obstacles. From this we can infer that the teachers' role significantly affects the students' motivation towards the speaking skill.

\subsubsection{Strategies used by Teachers to Overcome Motivation Hindering dynamics}

The role of teachers is to assist the students overcome that problem by motivating them that misunderstanding and the clarification can occur in any communication; it does not count what the speakers' language skill levels are. Instructors can also provide students with the needed strategies to use for comprehension (Bashir,2011). Consequently, teachers can be successful in constructing authentic practice environment within the classroom via sustaining students to use clarification phrases in classroom in the case of misunderstanding to respond positively. After enhancing a range of clarification strategies, students will be confident to deal with a variety of communication situations that they may occur outside the classroom. Secondly, effective instructors teach students speaking strategies; using minimal responses, recognizing script, and using language to talk about language, and then the students would develop their knowledge of the language and their confidence to use it. 


\subsubsection{Creating conducive Classroom Environment}

Madsa (2012) assumes that the good environment gives confidence to the students to speak correctly. Thus, the responsibility of teachers is trying to remove their nervousness, fear and anxiety by making it easy for them with supporting words. Actually, the role of teachers is making the class environment appropriate for speaking, and encouraging the students to talk by using different ways Generally, two factors are affecting students' speaking English. Either they do not find the words to express their thoughts, or they are afraid of making mistakes. Consequently, students sometimes make mistakes in speaking because of their shyness and nervousnessMaking a proper atmosphere where the students will not feel shy is very important, so they will volunteer to ask a question, give an answer, and give an opinion. According to the teachers' responses for the interview questions, how she creates a conducive speaking skill classroom environment. T4 said "One of the strategies I commonly use to encourage my students towards the speaking skill is building an interesting and a conducive classroom environment, because I believe that learners motivation will increase in a fear free classroom environment in which students can express their opinion and ideas freely". T5 stated that building a positive environment holds a great importance in students' motivation. When students feel relaxed, their level of interest is improved. She also noted that appealing to students' needs and interest renders them more motivated to learn. The teacher furthered that teachers' being interested in current issues and giving current examples make students more involved in the lesson. This way, they can build relationships and understand the lesson better.

Whereas from the questionnaires', response it was explored that, the teachers were controlling to keep the students silent and listen attentively. In relation to this, a student responded for the open ended question Item saying, "That their teachers help them in motivating towards the speaking skill in the classroom firstly, they tell us to be silent and listen to the speaking lesson attentively at the beginning of the class." From this it is possible that to conclude that teachers believed this strategy was particularly important in speaking class.

According, to the classroom observation results. The effectiveness of this strategy, was not encouraging most of the students did not show active participation during the presentation of speaking lesson, and most of them seem absent minded. This shows that the teachers' strategy that was used in the classroom to create suitable environment to the speaking skill seemed to be not effective to motivate the students.

\subsubsection{From Teacher to The Student-Centered Strategy}

To motivate students based on the teachers' interview responses, Students were always participating in practicing the speaking skill in the classroom. The teachers response was, "To make my students highly motivated towards the speaking skill, I mainly occupy the strategy of student-centered, I try to encourage students to be active participant in all process of learning the speaking skill, I simply act as a facilitator." The classroom observation showed that,

Students were not so active and responsive to the teachers' assigned strategies of teaching. Very few hardly took the floor. It seemed that they were accustomed to listening to the teacher passively. It was more teacher-centered strategy of teaching speaking. However, the greatest challenge with this strategy of teaching was integrating the speaking experiences of the students in to classroom instructions and keeping up students' interest and motivation. Hereby the students were not intrinsically motivated in speaking classes because they did participate actively in class activities. They need everything to be explained by the teacher. The teachers follow teacher-centered strategy of teaching in the class, which was not effective to motivate the students.

\subsubsection{Use of modern technology}

The interview question asked about the techniques that increase students' level of participation. The teacher pointed out that usage of modern technology promotes students' learning; thus, improve students' attention and interest. Modern technology computers, Visual aids, films, vedios etc attract their attention and make lesson more colourful for them. This way they begin to take more interest in the lesson. Similarly, using body language makes lesson more understandable, which increases students' motivation. When lesson gets clear and comprehensible, they feel more willing. She also emphasized the importance of communicative approach. When students are taught to communicate in English, they feel more willing and they see they can speak in English. However, she places a great value on grammar teaching, as well. She regards grammar as a tool for teaching speaking. Therefore, the technology is efficient in the classrooms since it can motivate students easily to practise their speaking skill. Ellis (1994) clarifies that effective language teachers should be energetic and creative because of the risk of losing motivation easily. Therefore, movies or music may help students' mood to improve. The classroom observation showed a positive sign that the students very enthusiastic using these technology. Brown (2003) indicates that the quality of language learning is improved because of internet and distance education. Web-learning offers well-selected activities and interactive learning.

\section{Conclusion:}

Speaking is the most important aspect in communication, yet students have had difficulties developing their capacity in speaking. It is not an easy process, and it requires time and effort. It is built on Affective factors, related directly to emotions, which determine the level of success in learning because of the fact that when we develop positive feelings during the language learning process, the possibility of achievement will directly increase. One of these affective factors is motivation in learning speaking skill in the classroom. Students' motivation towards the speaking skill was influenced by different variables such as understanding of the English language, especially inability to speak before people due to low vocabulary knowledge, lack of awareness, shyness, being afraid, lack of practicing the speaking skill in relation to other skills and giving less attention to the speaking skill in the classroom. The findings also revealed that the majority of 
the teachers did not use the right strategies that would help deal with the dynamic that influence students speaking motivation in the EFL classroom when teaching the speaking skills. The challenges that teachers encounter in using effective strategies were students' poor background knowledge of the English language and difficulties in applying specific strategies by the students. Therefore, what a teacher should use affective ways to develop students' speaking skills because many learners are not open to communicate; they might feel shy, afraid, or pressured by the classmates or from the teacher. Therefore, many teachers and researchers find out that the students should work in groups or in pairs so as to reduce those situations and feelings that learners find embarrassed to deal with.Teachers should persuade their students that learning the language is a good and important way for their future job. Thus, they should practise their speaking during classes. Teachers also have to create a comfortable atmosphere where students feel at ease when they participate.

\section{References}

[1].Ames, B, 1992. Classrooms; goals, structures, and student motivation. Journal of Educational Psychology, 84, 261271

[2].Anderson, W. 1989. Pictures for language learning; Cambridge University press.

[3].Asegid Lema. 2001. An investigation of student's perception of motivational techniques Arnold, B, 2003. Principles to develop real speaking skill

[4].Brown, D.H, 2002. Principle of language learning and teaching; White plains, NY; Longman

[5].BROWN, H.D. 2001. Teaching by principles, An interactive approach to language pedagogy. San Francisco State University: Longman.

[6].Bayget. M. (1987) Speaking. Oxford: OUP

[7].Brown. D. 1990.Principle of language learning and teaching. New Jersey; prentice hall. DECI, E.L. \& RYAN, R.M. 2000. "The "what" and "why" of goal pursuits: Human needs and the self-determination of behaviour", Psychological Inquiry 11(4): 227-268.

[8].DECI, E.L \& RYAN, R.M. 2008. Self-Determination Theory: A macro-theory of human motivation, development and health. Canadian Psychology 49(3): 182-185

[9].David J. Mendelsohn and Joan Rubin (eds) 1995. San Diego. CA Dominie press pp 236

[10]. Crowell, J.W, 2002. Educational research. New Jersey; person education international.

[11]. Crookes, G., \& Schmidt, R.1991. Motivation: Reopening the research agenda. Language Learning, 41, 469-512

[12]. Cunningworth A,1995. Choosing youre course book. London. Heinemane.

[13]. Dornyei, Z, 2001. Motivational strategies in language classroom. Cambridge, England; Cambridge University press.

[14]. Dornyei, Z. and K. Csizer, 1998. Then commandments for motivating language learners; results of an empirical study, language teaching research, 23, 203-229.

[15]. Elis, R.E., 1980. Teaching secondary English; Hong Kong Longman group Ltd.

[16]. Elis, 1977. Second language acquisition NY; OUP

[17]. Eshete, 2005, A study on problems students encounter in speaking with reference to Bahirdar University. Unpublished.

[18]. Fan,., Y 1993. English teaching forum

[19]. Farkuharsen, 1998. Analyzing the useof motivational strategies by EFL....Melta.

[20]. Field, J. 1998. Skills and strategies towards a new methodology for language skills: Oxford University press

[21]. Gardner, R.C., and W,Lambert, 1985.Attitudes and motivations in second language learning. Rowley, MA; Newbury House.

[22]. Gardner and Macintyre, 1991. Attitude and motivation in second language learning. Rowley.

[23]. Goh.C.C. M., 1998. How ESL learners with different language skill abilities use learning strategies and tactics. Language teaching resource 2(2), 124-144

[24]. Harachiewicz, J.M., 2000. Motivating the academically un motivated; a critical issue for the $21^{\text {st }}$ century. Review of educational research, 70, 151-179.

[25]. Harmer. J., 1991. The practice of English language teaching; Long man group Ltd

[26]. Harter.s., 1981. a new self - report scale of intrinsic orientation in the classroom; motivational and informational components, Development psychology , 17.3, 300-312.

[27]. Howarth, 2006. The problems teacher encounter to increase oral interaction among learners

[28]. Howarth, E.K(2OO1). Language anxiety and achievement. Annual review

[29]. JACKSON, P.W. 1990. Life in Classrooms. New York: Teachers College Press.

[30]. LONGWORTH, N. 2003. Lifelong learning in action: Transforming education in the 21th century. Great Britain: Kogan Page.

[31]. McDonough, S.2007. Motivation in ELT. Oxford ELT Journal. (61/4): 369-371. http://eltj.oxfordjournals.org/cgi/reprint/61/4/369?maxtoshow=\&HITS=10\&hits=10\&RESULTF

ORMAT=\&fulltext=motivation\&searchid=1\&FIRSTINDEX=0\&resourcetype=HWCIT (accessed January 7,2009).

[32]. Lambert, W. E. 1974. Culture and language as factors in learning and education. I n F.F. Aboud and R.D Meade (Eds). Cultural factors in learning and education (pp. 91-122) Bellingham; Western Washington university.

[33]. Lukmani, Y.M. 1972. Motivation to learn and language proficiency. Language Learning 22, 261273

[34]. Lucas. R.I. 1990. A study on the intrinsic motivaton factors in second languag acquisition Little Wood, 1981. Communicative language; Cambridge University press.

[35]. Locke, E.A. \& Latham, G.P. (1990). A Theory of Goal Setting \& Task Performance. Englewood Cliffs, NJ: Prentice Hall. Logan, G.E 
[36]. Lougharn. J.J., 1996. Developing reflective practice; learning about teaching and learning through modeling. London; flamer press. 1988.

[37]. MCMILLAN, J.H. \& Schumacher, S. 1997. Research in education: A conceptual introduction. New York: Longman

[38]. Mark Lepper, "' Motivational considerations in the study of instructive "COGNITION and INSTRUCTION 5, 4 1988. 289-309

[39]. Maeher, M. L., \& Fyans, L. J., Jr.1989. School culture, motivation, and achievement. In M. L. Maehr \& C. Ames (Eds.), Advances in motivation and achievement: Vol. 6. Motivation enhancing environments (pp. 215-247). Greenwich, CT: JAI Press.

[40]. Maslow. Research in higher Education journal five key ingredients of motivation

[41]. Maslow, A.1943. Theory of human motivation. Psychological review, 50, 370-396

[42]. Maslow's, 1970. Theory of human need. Hierarchy of need

[43]. Maehr, M.L and H.A. Meyer, 1997. understanding motivation and schooling; where we have been, where we are, and where we are to go. Educational psychology review, 9, 371409.

[44]. Mayers, I . The mayers -Briggs Type Indicators. Palo, Alto, CA consulting psychologists' press.

[45]. Mc Millan,J.H.,and D.R Forsyth, 1991, what theories of motivation say about why learners learn. In RJ Menges and M.D. Svinicki [Eds], college teaching; from theories to practice. New direction for teaching and learning, No, 45 [pp. 39-52] San fransisco; Jossey Bass.

[46]. Mcl,aren and Madrid. (1994: 144-145) Four main factors which influence the students' motivation in the classroom.

[47]. Mebratu Halefom, 1999. Motivation in speaking classes of college English at BU, un published research thesis.

[48]. Mendelsohn, D.J. , and J. Rubin, [Eds.], 1995. A guide for the teaching of second language. San Diego, CA; Dominie

[49]. Mo,L. 1999. On the participants of English course and their functions. Journal of PLA

[50]. University of foreign language, 109(4), 75-78

[51]. Mo, L. 2000. On stylistic feature of real learning materials. Journal of foreign language university, 20(4), 16-19

[52]. Moges. 2004. Teachers attitude towards language teaching practical problem

[53]. Moges, 2006. Asudy of speaking and listning strategy training and achievement: unpublished research thesis

[54]. Morrison, K. 1996. Developing reflective practice in higher degree students through a learning journal. Studies in higher education, 31, 317-332.

[55]. M. Williams and R. Burden, Psychology for Language Teachers, Cambridge University Press

[56]. Norton, B. 1998. Using journals in second language research and teaching. In J. Smoke (Ed). Adult ESL; Politics, pedagogy and participation in classroom and community program [pp. 55-71]. Hill side, N.S; Erlbaum.

[57]. Negash Alemu. 2008. A comparative study of the method of teaching speaking

[58]. Oller, J. W., Baca, L. \& Vigil, F. (1977). Attitudes and attained proficiency in ESL: a sociolinguistic study of Mexican-Americans in the Southeast. TESOL Quarterly, 11, 173-183.

[59]. Pierce, L.V. 1998. Teaching strategies for developing oral skill, a forum anthology.

[60]. Richards, J.C. 1992. Dictionary of language teaching and applied linguistics (second ed.) Essex; Longman.

[61]. Rivers, W.M. ,1983 Communicating naturally in second language, Cambridge University press,

[62]. Rixon, S., 1986 Developing language skill. London. Macmillan publisher Ltd.

[63]. Roots, M. 1990. Language learning. London: Longman

[64]. Roots, M. 2001. In r.Carct and D. Nun an (Eds.), THE Cambridge guide to teaching English to other speakers of other language, (pp. 7-13). Cambridge: Cambridge university press.

[65]. Ruhar. X. 2003. How motivation affects foreign language learning: Long man

[66]. Sheldon L. 1987. ELT textbooks and materials, problem in evaluation and development. ELT document. Vol. 126

[67]. Suleman, I.S. 1993. Knowledge and teaching: Foundation of new reform, 57 (1), 1-21

[68]. Tewelde, 1988. Motivation in speaking classes at B.U, unpublished research thesis

[69]. Tremblay, P. F., Goldberg, M. P., \& Gardner, R. C. (1995). Trait and state motivation and the acquisition of Hebrew vocabulary. Canadian Journal of Behavioural Science, 27, 356-370.

[70]. Underwood, M, 1989 Teaching foreign language, New York: Longman UK, Ltd.

[71]. Wiliams, M. Burden, R.L. 1997. Psychology for language teachers. England: Cambridge University press 